Article

\title{
Quantitative Analysis of Urban Pluvial Flood Alleviation by Open Surface Water Systems in New Towns: Comparing Almere and Tianjin Eco-City
}

\section{Zhengnan Zhou ${ }^{1,2, *}$, Lei Qu ${ }^{3}$ and Tao Zou ${ }^{4}$}

1 School of Architecture, Tsinghua University, 100084 Beijing, China

2 Key Laboratory of Eco Planning and Green Building (Tsinghua University), Ministry of Education, 100084 Beijing, China

3 Faculty of Architecture and the Built Environment, Delft University of Technology, P.O. Box 5043, 2600 GA Delft, The Netherlands; E-Mail: 1.qu@tudelft.nl

4 Tsinghua Tongheng Urban Planning and Design Institute, 100085 Beijing, China;

E-Mail: zoutao@thupdi.com

* Author to whom correspondence should be addressed; E-Mail: zznan@tsinghua.edu.cn;

Tel.: +86-10-6277-3094; Fax: +86-10-6277-0314.

Academic Editor: Thorsten Schuetze

Received: 5 July 2015 / Accepted: 22 September 2015 / Published: 29 September 2015

\begin{abstract}
Increased surface runoff generated in urban areas due to larger proportion of impervious surfaces has, in many cases, exceeded the capacity of urban drainage systems. In response to such challenge, this paper introduces the quantitative analysis of pluvial flood alleviation by open surface water systems in the case of Almere in the Netherlands and compares it with Tianjin Eco-City in China, with the aim of optimizing land use planning and urban design for new urban districts. The methodology is a combination of quantitative and qualitative analysis. With the analytical tool of ArcGIS, the authors have investigated the influence of spatial distribution of surface water system on the reduction of pluvial flood risks. The conclusions include some preliminary principles: (1) a densely distributed surface water network is preferable; (2) areas farther away from water body require water sensitive spatial intervention; and (3) optimizing the allocation of different types of ground surface could contribute to pluvial flood alleviation. An alternative design proposal for a typical urban block in Tianjin Eco-City has been put forward to illustrate these principles.
\end{abstract}


Keywords: Pluvial flood; runoff coefficient; surface water; ground surface

\section{Introduction}

Although there is still considerable uncertainty about global climate change, it is clear that an increasing intensity of extreme weather events, such as heavy storms/precipitation events, is noticeable and anticipated in many regions in the world [1-3]. This will increase the risks of pluvial flooding in city regions that are undergoing a fast urbanization, where vast urban construction has generated growing impervious surfaces [4,5]. In recent years, cities in China have experienced a higher intensity and frequency of heavy rainfalls. For instance, the total precipitation during a rainfall event on 26 July 2012 in Tianjin metropolitan area reached $300 \mathrm{~mm}$, which amounts highest in local history. Just several days earlier than that, on 21 and 22 July 2012, the heaviest storm in 61 years hit Beijing. Severe water logging appeared throughout the urban area, with numerous cars drowned and damaged, 61 citizens died, costing 1.83 billion dollars in total economic loss. Since then, municipal governments have taken great effort to seek more climate adaptive urban development strategies.

Currently, most Chinese cities manage storm water with technical solutions based on underground drainage systems. As defined in the "Code for design of outdoor wastewater engineering" [6], storm water sewer systems shall be designed for a return period from 0.5 to 3 years. A higher standard of 3 to 5 years' return period is applied in areas of higher importance or higher flooding risks. These systems can typically manage 30 to $50 \mathrm{~mm}$ of precipitation per hour without prominent risks of pluvial flooding. However, once it exceeds $50 \mathrm{~mm}$ per hour, serious water logging problems are very likely to occur. The latest "Code for design of outdoor wastewater engineering" [7] encourages choosing the upper limits of design standards. However, it is still much lower than European standards, which require storm water sewer systems designed for a return period from 5 to 10 years, in accordance with the European standard for planning, design and operation of drain and sewer systems outside buildings [8].

Raising the standard is not the only concern in Europe. Increased pressures on water resources, and increasing awareness of the environmental impact of storm water discharge on quality of receiving water has led to alternative approaches in managing the urban water cycle. It is expected that extreme weather events usually generate a great amount of surface runoff in urban built up areas. What is now being found is that, due to the high percentage of impervious surfaces created by the urbanization process, even small storm events can generate large amounts of surface runoff. During extreme weather events, surface runoff must be removed from built up areas rapidly enough to prevent water logging. This is usually accomplished by means of underground drainage, which conveys surface runoff away more rapidly than natural drainage paths. However, such rapid conveyance of runoff can lead to flooding of the streams that receive the runoff. This can occur much more frequently in an urbanized setting, due to the excessive amount of runoff production [5,9].

There is increasing awareness in Europe that to cope with the heightened urban flood risks, both underground and above ground water systems should be developed [10-13]. An alternative way of thinking is to manage rainwater as a resource rather than a waste stream. With this in mind, runoff could be controlled at the point of generation, instead of simply being discharged [9]. For example, in 
the Netherlands, creating an increased amount of space for containing water in the built up areas has become the new spatial policy, with concepts of "living with water" well promoted in the latest policy documents [14]. Reservation of areas for longer-term water-retention in, for example, new towns of Ijsselmeerpolders would keep options open for substantial fluctuations in the water-table [15], while in Rotterdam, increasing water storage capacity is being implemented through urban renewal programs [16]. In the same line, the Netherlands has also developed the "strategy for sustainable water management in the 21 st century". One of the main concepts of the strategy is to reduce, as much as possible, the discharge of (comparably clean) rainwater. Priority is given to decentralized retention, collection of rainwater, and on-site storage in surface water bodies like ditches, ponds, lakes, or water facilities, such as tanks. Only surplus water that can neither be retained nor stored is discharged to rivers or canals. This strategy is supported by the fact that, for new urban developments in the Dutch lowlands, the integration of open surface water bodies is compulsory, being required by district water boards. There is a regulation making sure that a specific portion (e.g., $5 \%$ or $10 \%$ ) of the land surface of new urban developments is left for open water bodies [17].

Besides the general principles and qualitative approaches, storm water management also requires quantitative data and methods for making decisions in investments [18]. One of the most important research approaches is computer simulation by means of software tools developed for hydrological engineers. For instance, the EPA (US Environmental Protection Agency) Storm Water Management Model (SWMM), a dynamic rainfall-runoff simulation model used for single event or long-term (continuous) simulation of runoff quantity and quality from primarily urban areas, can be used for evaluating LID (Low Impact Development) interventions, such as permeable pavement, low-lying grass swale, etc. In addition to these, storm water management BMPs (Best Management Practices) have also been widely studied and referred to, as control measures to mitigate changes to both quantity and quality of urban runoff, caused by land use transformations. There are a variety of BMPs available, and EPA has published a list of storm water BMPs for local governments, builders and property owners ("National Menu of Storm water Best Management Practices"). However, there are uncertainties in effectiveness because BMP monitoring requires a high degree of expertise [19]. Besides, the BMPs approach is also highly case sensitive. "Many different BMPs and several distinct criteria (technical, hydraulic, environmental, social, economic, maintenance criteria) need to be considered in the decision-making process" [20].

The remaining questions include, for instance, how could urban planners have a better understanding on the quantitative relationship between planning interventions and pluvial flood alleviation? What kind of correlated principles and guidelines could be used for planning interventions in practice? Is there an analytical tool for such quantitative study?

This paper tries to answer these questions, by comparing the quantitative and qualitative analysis of two study cases: a Dutch and a Chinese new town. A conceptual framework has been setup, integrating spatial planning of open surface water systems, LID strategies and BMPs. The basic idea is in line with the above-mentioned concepts of "living with water": considering the balance of water retention and discharge in different scales, stagnant water generated by heavy rainfall in built up areas can be collected on site, and retained in a nearby surface water system, where water retention and recycling within the neighborhood could be implemented when needed. This is based on the precondition that space could be created along the surface water system for the purpose of water retention during 
extreme weather events. Within such a conceptual framework, the focus of this research is more on optimizing the spatial structure of the surface water system for pluvial flood alleviation.

\section{Method}

In order to achieve this goal, quantitative analysis on runoff coefficient of the water front areas is made. ArcGIS is used as the analytical tool, with two mathematical formulas embedded in it: Kerby formula and another one calculating weighted average runoff coefficient. The aim is to estimate the influence of the distribution of different types of ground surface on the weighted average runoff coefficient in a certain range of water front areas.

It should be clear that the two cases are both hierologically isolated, thus they excluded possible side effects of flood risk via the waterways when these might receive excess water and surcharge. Apart from this, the research is highly focused on the possible flood risk related effect caused by spatial planning issues, i.e., spatial distribution of open water system, and land-use planning of water front area. These are more of two-dimensional studies, and other impact factors for flood risk, such as topography, the arrangement of buildings, and grade/slope of roads, are excluded.

\subsection{The Range of Overland Flow Distance in Kerby Formula}

In the waterfront areas, rainwater collected by roof, road, pavement, and other types of ground surfaces during a heavy rainstorm could be directed into the surrounding surface water system, thus reducing the water volume that enters the underground sewer system. Normally, such waterfront areas include those within a certain distance from the water body. In order to get a rough idea of the range of such distances that involves overland flow, calculations are made based on the Kerby formula [21], which is normally used to estimate the time of concentration for a plane with sheet flow [22]. In the Kerby formula, the length of overland flow (L) was roughly defined as less than 400 meters, which is considered as an upper limit in practice, and generally shorter values are expected [23,24].

$$
\mathrm{t}_{\mathrm{c}}=1.45(\mathrm{NL} / \sqrt{s})^{0.467}
$$

In this formula, $t_{c}$ is the overland flow time of concentration in minutes; $\mathrm{N}$ is a dimensionless retardance coefficient, a parameter related to the type of land surface; $\mathrm{L}$ is the overland flow length in meters; and $\mathrm{S}$ is the dimensionless slope of terrain conveying the overland flow. Since this formula does not account for the rainfall intensity, it is only valid for a limited range of rainfall intensities [25]. Nevertheless, to define the precise length of overland flow in built up areas during heavy rainfall is nearly impossible, neither is it the purpose of this calculation. Instead, the aim is to get a rough idea of its range, so as to further define water front areas that may benefit from a surface water system, in order to provide a solution to the problem of water logging.

According to the "Code for design of outdoor wastewater engineering" [7] in China, time of concentration should be approximately 5-15 min. This is in reference to the rainwater runoff from the furthest point to the drainage inlet, indicating the time range before water stagnation occurs (depends on the type of ground surface and slope of the terrain). Such a standard was used here to calculate the overland flow into the water body, instead of the drainage inlet. For calculating the overland flow length " $L$ ", the average of 10 min was adopted for " $t c$ "; an empirical data of $1 \%$ was used for "S"; and 
according to Table 1 [23], the data of paved surface (0.02) was chosen for " $\mathrm{N}$ " (since urban districts are the focus). Thus, the resulting overland flow length $\mathrm{L}$ is $300 \mathrm{~m}$. This refers to an ideal situation in the Chinese context of a fully paved and relatively flat waterfront area, where open surface water system could collect the surface runoff within $300 \mathrm{~m}$.

Table 1. Typical values of retardance coefficient N of Kerby formula (1959).

\begin{tabular}{ll}
\hline Generalized terrain description & Dimensionless retardance coefficient $(\mathbf{N})$ \\
\hline Pavement & 0.02 \\
Smooth, bare, packed soil & 0.10 \\
Poor grass/cultivated row crops/rough packed surfaces & 0.20 \\
Pasture/average grass & 0.40 \\
Deciduous forest & 0.60 \\
Dense grass/coniferous forest litter/deciduous forest with deep litter & 0.80 \\
\hline
\end{tabular}

\section{2. "Equivalent" Weighted Average Runoff Coefficient}

In this research, the term "runoff coefficient" is often mentioned, and refers to the ratio of total stream flow volume to the total precipitation over a certain ground area and time [26]. Weighted average calculation on the runoff coefficient of an urban block with various types of land surface is also made to indicate the general pluvial flood risks of the block. According to the "Code for design of outdoor wastewater engineering" [7], methods such as increasing permeable surfaces and storing water onsite will be implemented in areas with weighted average runoff coefficient of more than 0.7 . This helps to frame the methodology of this research.

As mentioned earlier, with a precondition of enough space for water retention, the surface water system contributes to collecting and containing rainwater from the waterfront areas within a certain distance, reducing the amount of water discharge during heavy rainfall. Thus, considering the effects of pluvial flood alleviation, having this type of surface water system within an urban area is equivalent to a reduced runoff coefficient of the whole block, compared to the scenario of having no such surface water system in it. In other words, during extreme weather events, the surface water system within the urban block would function more as a series of water retention ponds, than part of a water drainage system. In this case, although the total amount of surface runoff stays the same, the amount of storm water that needs to be discharged has been largely reduced. Of course, such influence varies according to the distance to the surface water body: the longer the distance is, the smaller the influence would be.

To make it easier for calculation, study areas are classified into four ranges: 0 to $100 \mathrm{~m}, 100$ to $200 \mathrm{~m}$, 200 to $300 \mathrm{~m}$, and above $300 \mathrm{~m}$ away from the main water body (waterways, ditches, lakes, etc.). Due to the fact that roadbeds of highways and railways, as well as the canal embankment, are all higher than the ground level, the influence of the surface water system that is on the other side and blocked by highways, railways or canals is not considered. Based on this approach, the "equivalent" weighted average runoff coefficient of an urban block can be calculated with the following formula:

$$
\begin{aligned}
\Psi^{\prime}= & {\left[\mathrm{m}_{1} \mu\left(\mathrm{B}_{1} \Psi_{\mathrm{B}}+\mathrm{R}_{1} \Psi_{\mathrm{R}}+\mathrm{P}_{1} \Psi_{\mathrm{P}}+\mathrm{G}_{1} \Psi_{\mathrm{G}}\right)+\mathrm{m}_{2} \mu\left(\mathrm{B}_{2} \Psi_{\mathrm{B}}+\mathrm{R}_{2} \Psi_{\mathrm{R}}+\mathrm{P}_{2} \Psi_{\mathrm{P}}+\mathrm{G}_{2} \Psi_{\mathrm{G}}\right)+\right.} \\
& \left.\mathrm{m}_{3} \mu\left(\mathrm{B}_{3} \Psi_{\mathrm{B}}+\mathrm{R}_{3} \Psi_{\mathrm{R}}+\mathrm{P}_{3} \Psi_{\mathrm{P}}+\mathrm{G}_{3} \Psi_{\mathrm{G}}\right)+\left(\mathrm{B}_{4} \Psi_{\mathrm{B}}+\mathrm{R}_{4} \Psi_{\mathrm{R}}+\mathrm{P}_{4} \Psi_{\mathrm{P}}+\mathrm{G}_{4} \Psi_{\mathrm{G}}\right)\right] / \mathrm{A}
\end{aligned}
$$


$\Psi$ ': The "equivalent" weighted average runoff coefficient of the whole area, considering the influence of the surface water system on water retention.

A: The total land use area.

B1/B2/B3/B4: Total roof area within the zones that are 0-100 m/100-200 m/200-300 m/above $300 \mathrm{~m}$ away from the water body, respectively.

$\mathrm{R} 1 / \mathrm{R} 2 / \mathrm{R} 3 / \mathrm{R} 4:$ Total road surface area within the zones that are 0-100 m/100-200 m/200-300 m/ above $300 \mathrm{~m}$ away from the water body, respectively.

P1/P2/P3/P4: Total pavement area within the zones that are 0-100 m/100-200 m/200-300 m/above $300 \mathrm{~m}$ away from the water body respectively.

G1/G2/G3/G4: Total green space area within the zones that are 0-100 m/100-200 m/200-300 m/ above $300 \mathrm{~m}$ away from the water body, respectively.

$\Psi_{\mathrm{B}} / \Psi_{\mathrm{R}} / \Psi_{\mathrm{P}} / \Psi_{\mathrm{G}}$ : Runoff coefficient of roof/road/pavement/green space, respectively.

$\mathrm{m} 1 / \mathrm{m} 2 / \mathrm{m} 3$ : Reduction factors within the zones that are 0-100 m/100-200 m/200-300 $\mathrm{m}$ away from the water body, respectively.

$\mu$ : Correction factors for the stagnation conditions.

The ground surface is classified into four major types: roof, road surface, pavement, and green space. With reference to the "Code for design of outdoor wastewater engineering" [7], values of the runoff coefficient are defined as: $\Psi_{\mathrm{B}}($ roof $)=0.95 ; \Psi_{\mathrm{R}}($ road surface $)=0.85 ; \Psi_{\mathrm{P}}($ pavement $)=0.55 ; \Psi_{\mathrm{G}}$ $($ green space $)=0.2$. The reduction factors of the three zones that are $0-100 \mathrm{~m} / 100-200 \mathrm{~m} / 200-300 \mathrm{~m}$ away from the waterfront $(\mathrm{m} 1 / \mathrm{m} 2 / \mathrm{m} 3)$ are $0.25 / 0.5 / 0.75$, respectively. The value of $\mu$ is in view of reduction factors. Furthermore, it is the correction factor for the stagnation conditions, which is defined as 1.2 in this research, considering the stagnation effect of the terrain and buildings (in typical urban blocks) on the rainwater runoff.

\subsection{ArcGIS Statistics}

The model is simplified for practical reason, which is based on the following conditions: (1) the two formulas can be correlated, since the difference between the amount of surface runoff and overland flow within such a fine scale is very small and can be ignored, although it might become quite an issue in larger hydrological regions; and (2) the purpose of calculating the weighted average runoff coefficient is to indicate the risks of pluvial flooding caused by an urban block, but not the actual amount of overland flow, therefore the influence of gutters, sidewalk and sewer systems can be neglected.

With the application of GIS tools, it is possible to use these two formulas for quantitative analysis, and generate geographic information or statistics on runoff coefficient or land use typologies. Such a method could be used for different scenarios, with or without the influence of the surface water system. Comparing different scenarios in ArcGIS can, on the one hand, quantify the contribution of open surface water system in reducing water discharge, while on the other hand, optimize spatial planning and design for surface water system towards a desired scenario. 


\section{Case Study Description: Almere and Tianjin Eco-City}

In order to demonstrate the above mentioned method, this paper introduces two study cases: Almere in the Netherlands and Tianjin Eco-City in China (Figures 1 and 2), which are both fast developing new towns in embanked areas, facing the challenge of pluvial flood risks. Two urban areas have been chosen to conduct the quantitative analysis, Almere Stad and Tianjin Animation Park, representing the two new towns, respectively.

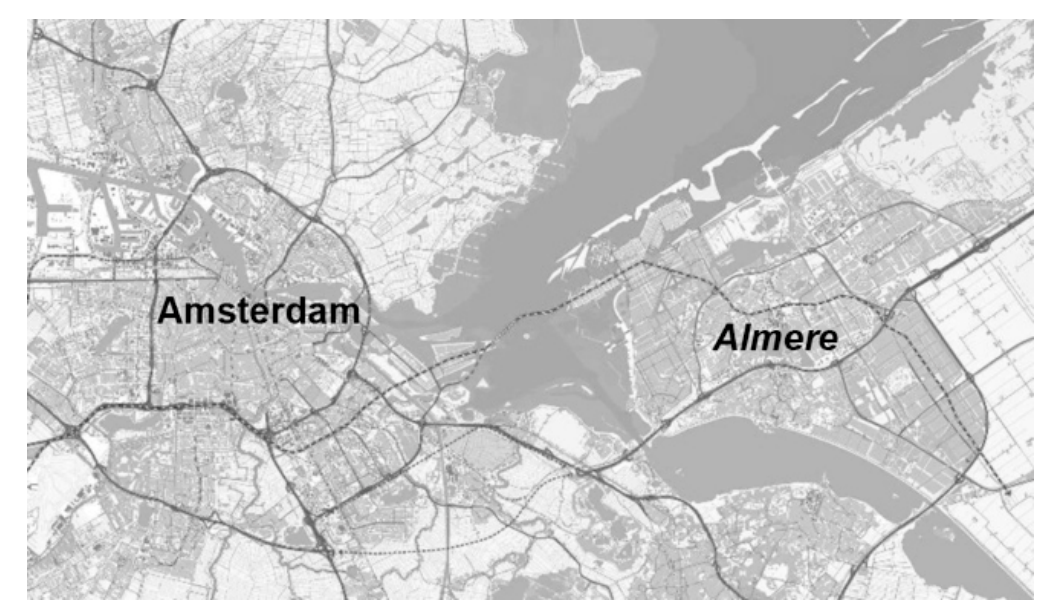

Figure 1. The location of Almere.

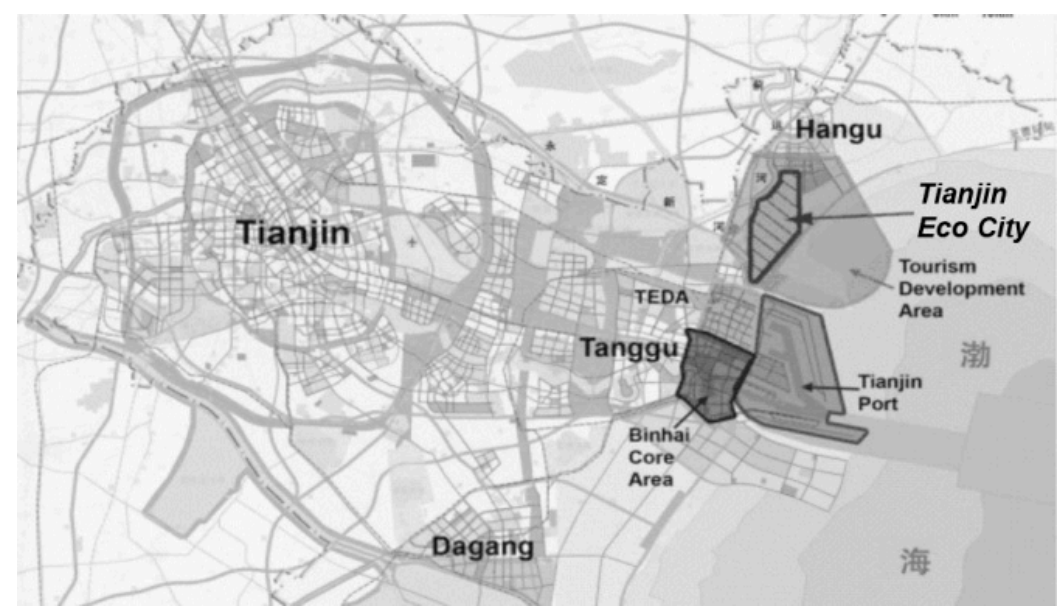

Figure 2. The location of Tianjin Eco-City.

\subsection{The Case of Almere}

\subsubsection{The Surface Water System}

Due to constraints in the drainage of the polders, the lower lying parts of the Netherlands are more vulnerable to flood risks. This was reflected in damages caused by the heavy rainfall in the Netherlands in 1998, 2000, 2001 [27,28], and, more recently, on 26 August 2010 in the eastern part of The Netherlands [29].

Being developed on reclaimed land from the sea, Almere has been facing such risks since its early phase of development. Because of this, its water system was designed mainly for a safe and well-functioning 
living environment. Currently, the city is seeking for an integrated water management and spatial development model in line with the national policy of "living with water".

Following the Dutch water culture and urban development tradition, Almere has a very densely distributed surface water system, carefully managed, with diversified functions related to it. Such a surface water system has contributed to the creation of urban space and identity of landscape, while at the same time, has offered a solution to many of the water related problems that the city is facing. The surface water system of Almere consists of lakes, canals, watercourses and ditches (Figure 3).

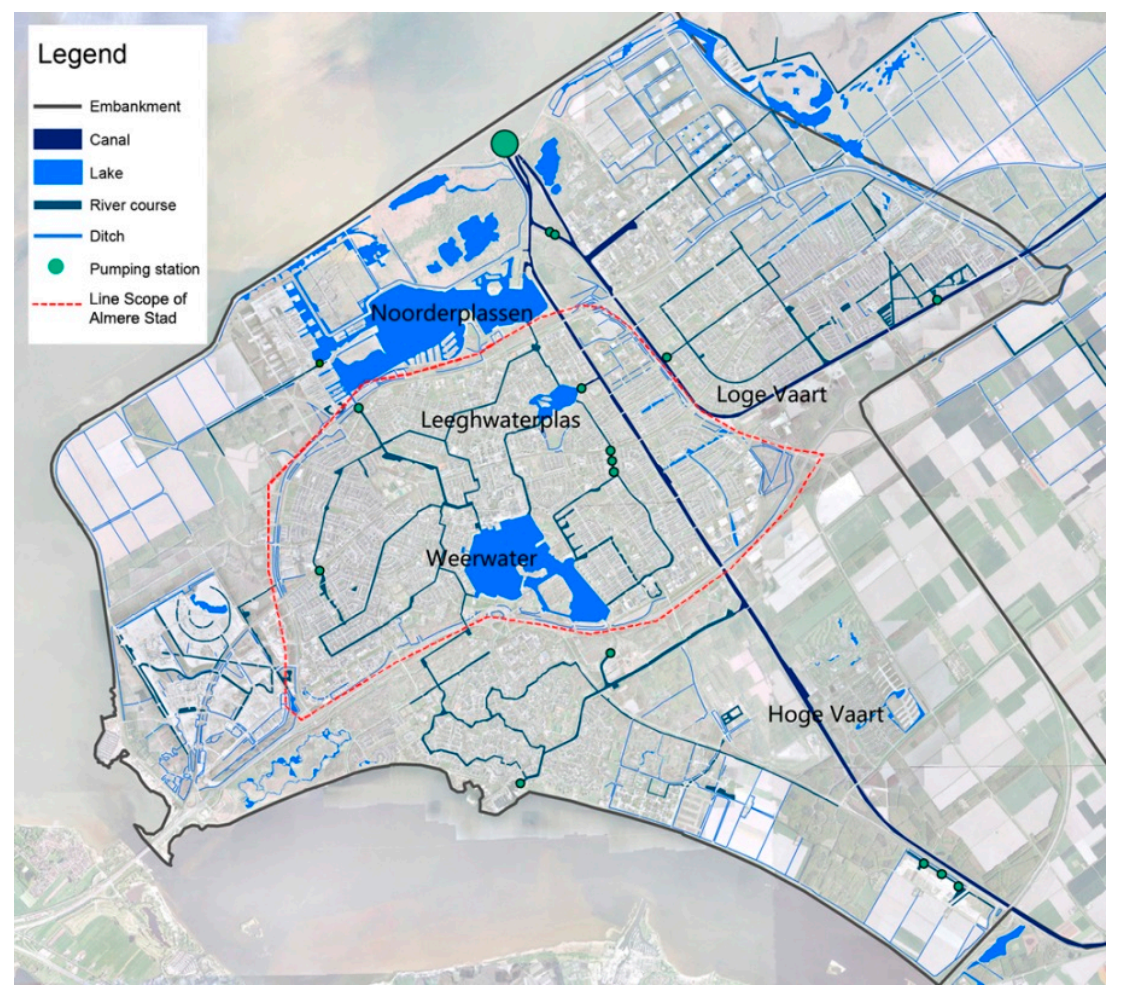

Figure 3. Spatial distribution of the surface water system in Almere.

\subsubsection{The Ground Surface Typologies}

In this research, Almere Stad was chosen as the focus area of the Almere case (area within the dashed line in Figure 3, which is $30 \mathrm{~km}^{2}$ in total). It is surrounded by highway (A6) and provincial road (N702), with a railway line running through it. Its surface water system includes the Weerwater lake, Leeghwaterplas lake, part of the Hoge Vaart canal, and a relatively dense watercourse network, which defines the spatial borders of urban blocks in Almere Stad. Since the lakes and watercourses have relatively low water levels and a large capacity for retaining water, they could collect and retain rainwater from the surrounding urban areas during rainstorms.

Figure 4 shows the spatial distribution of the four types of ground surface in Almere Stad (roof, road, pavement and green space), which were already classified into four waterfront zones that are $0-100 \mathrm{~m}$, 100-200 m, 200-300 m, and above $300 \mathrm{~m}$ away from the water body, respectively. As a result, percentage of the four main types of ground surface is shown in Figure 5. 


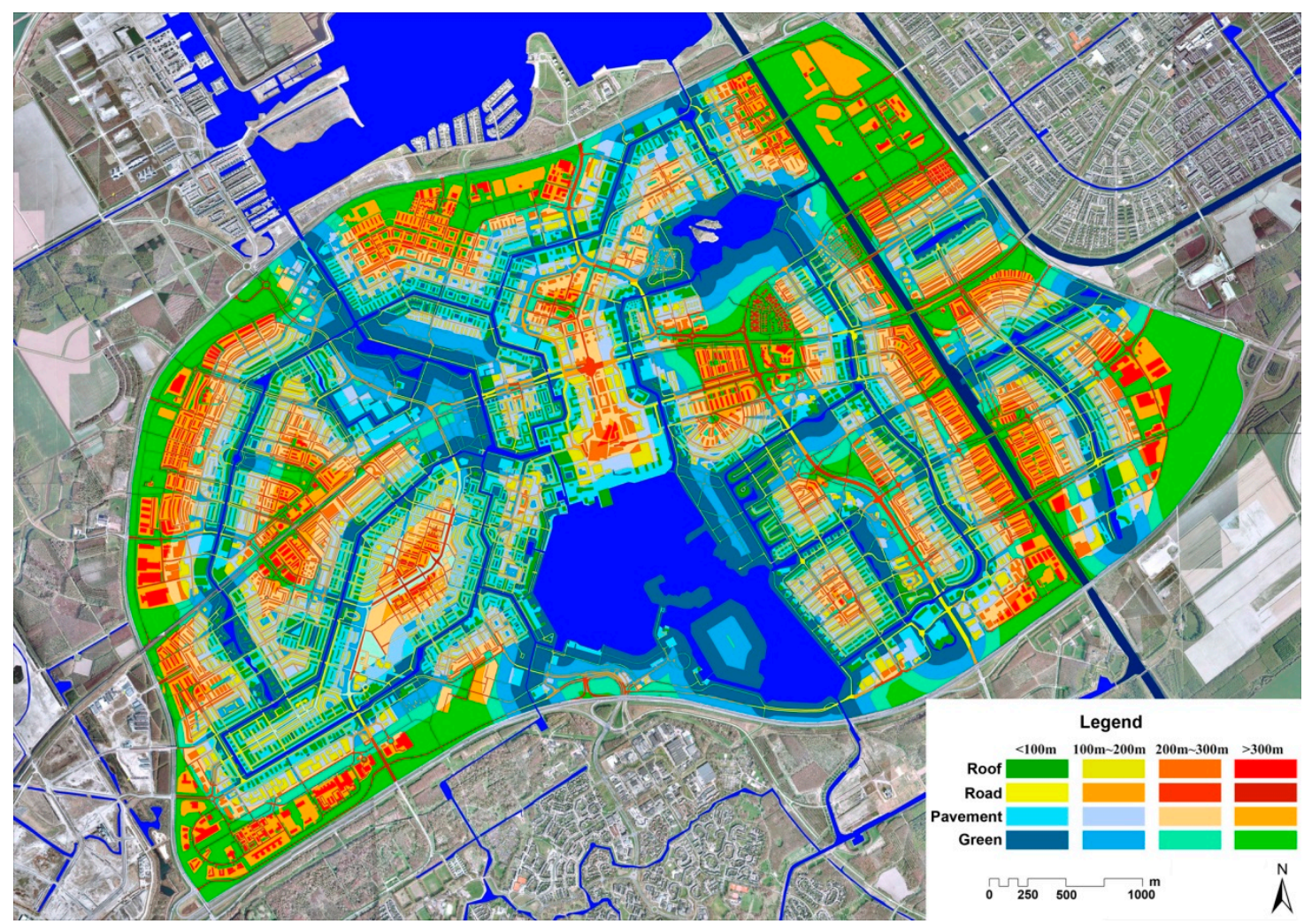

Figure 4. The spatial distribution of different types of ground surface in Almere Stad.

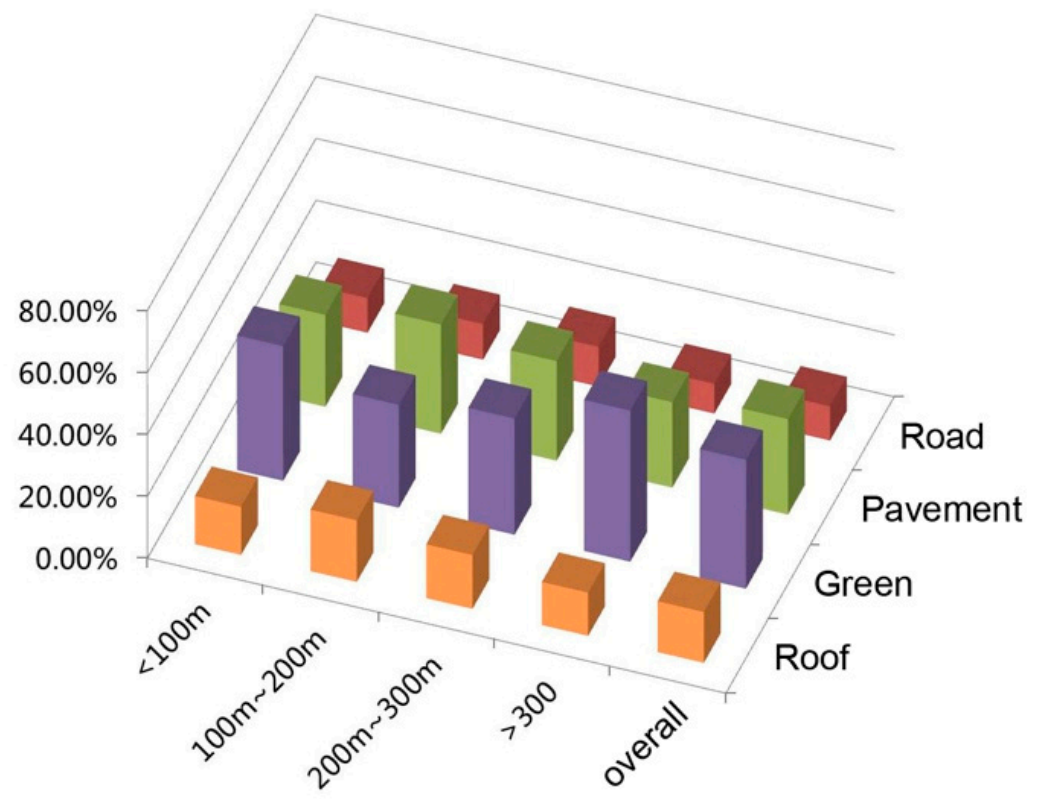

Figure 5. Statistics on ground surface in Almere Stad.

In general, there is more green space than any other types of ground surface in the whole district; while, in each zone, the percentage of each ground surface varies slightly. In the "above $300 \mathrm{~m}$ zone", green space occupies around $49 \%$ of the total ground surface, which is the highest compared to the other zones. There is also a high percentage of green space (43\%) in the " $0-100 \mathrm{~m}$ zone". Building roof and pavement are mainly distributed in the "100-200 m zone" and "200-300 m zone", where 
urban space is mainly composed of buildings, streets and squares. The "100-200 m zone" has the highest percentage of roof and pavement (around 20\% and 35\%, respectively), and the lowest percentage of green space (around 33\%), indicating the most densely built area in Almere Stad.

\subsection{The Case of Tianjin Eco-City}

\subsubsection{The Surface Water System}

Unlike the Almere case where the surface water system has been developed over the past three decades, Tianjin Eco-City is still under large-scale construction. According to the master plan, a new surface water system has been planned for this Eco New Town, including one lake (Qingjing Lake), four artificial streams (Huifeng Stream, Ganlu Stream, Hupo Stream and Dongfeng Stream) and one old watercourse (the old course of Ji Canal) (Figure 6).

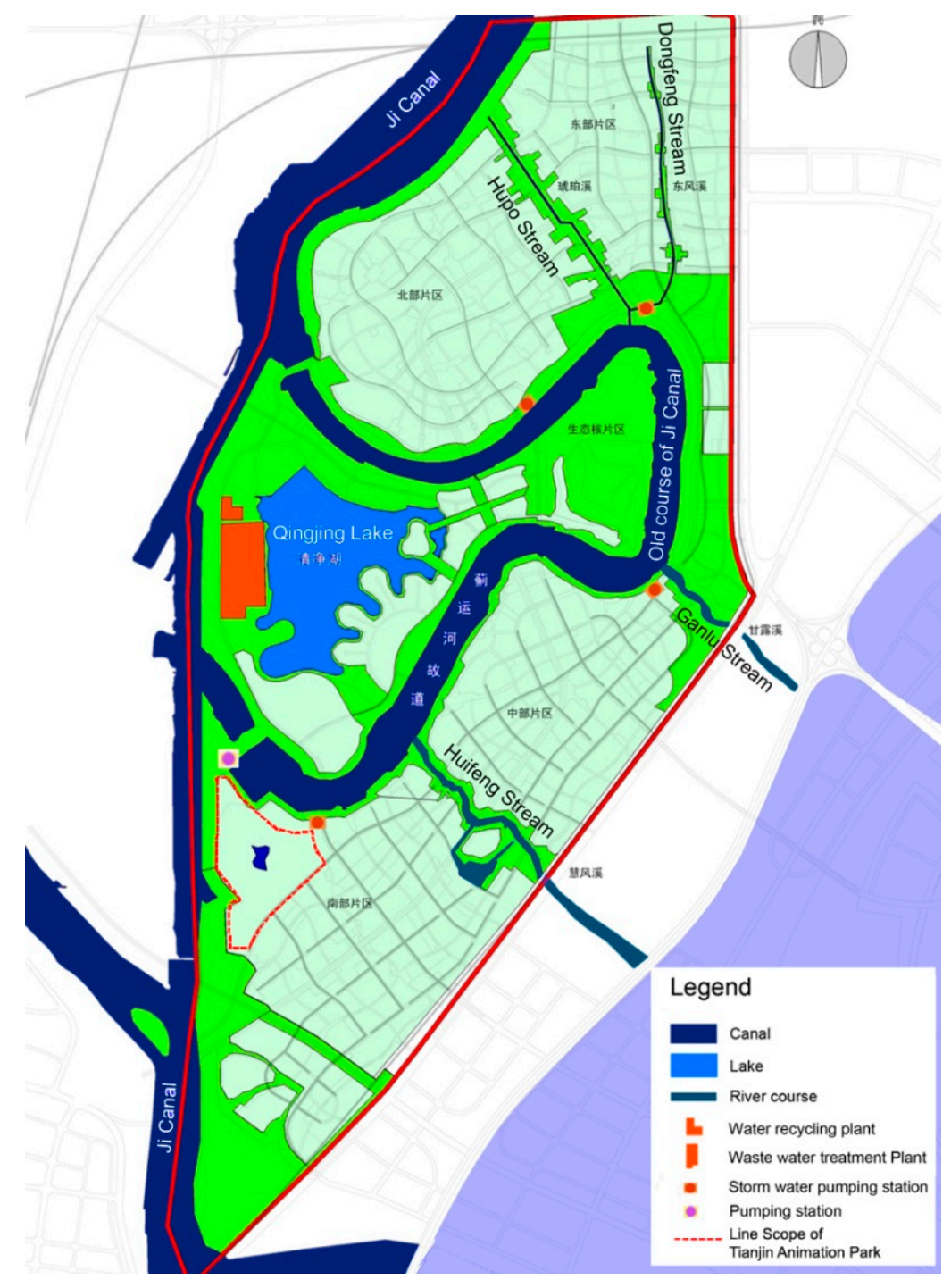

Figure 6. The planned surface water system in Tianjin Eco-City.

Compared to Almere, Tianjin Eco-City has waterways that are much wider but a waterway network that is far less dense in the built up areas. This is partly related to the fact that Tianjin is a city seriously lacking water resources (as stated in Tianjin Major Functional Zones Planning, 2012). 


\subsubsection{The Ground Surface Typologies}

With the same method, ground surface typologies in Tianjin Eco-City was also examined. Considering the fact that most part of this new town has not yet been built, it is not possible to fully examine the whole site. Thus one nearly built block, National Animation and Comic Industry Comprehensive Demonstration Park (Tianjin Animation Park) is chosen as the focus area.

Tianjin Animation Park (area within the dashed line in Figure 6) has a total area around $0.9 \mathrm{~km}^{2}$. It is located on the east bank of Ji Canal with the old course of Ji Canal on its Northeast border. In the middle of the block, there is an isolated artificial pond of around 10,000 $\mathrm{m}^{2}$, surrounded by high-density public buildings. Before construction of Tianjin Animation Park, the adjacent Ji Canal and the old course of Ji Canal both had dikes along them, separating the site from the watercourses. During the construction process, the dike along the old course of Ji Canal was demolished and replaced with green space. This has made it possible for the old course of Ji Canal to influence the pluvial flood alleviation for this block (Figure 7).

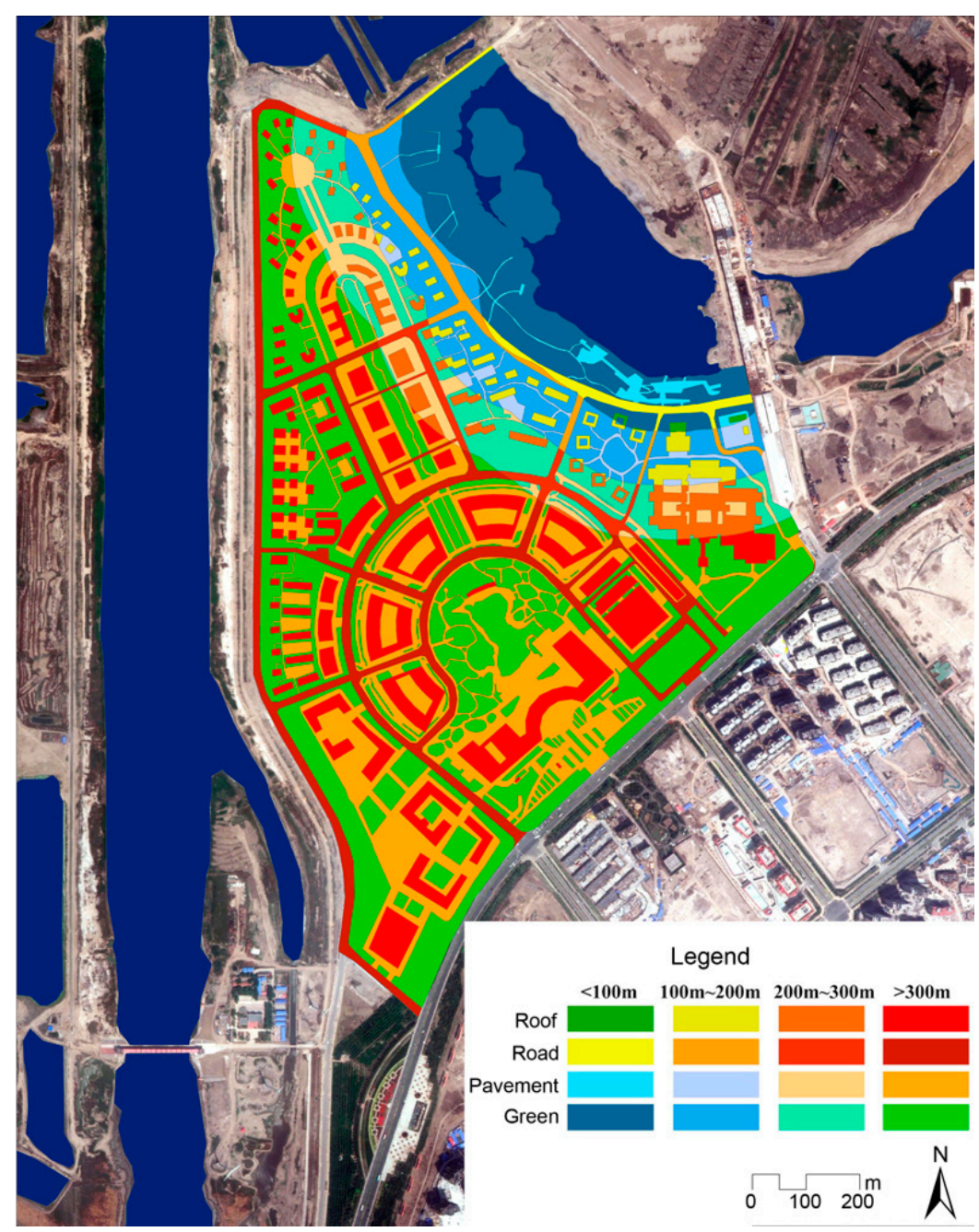

Figure 7. Spatial distribution of ground surface in Tianjin Animation Park.

The spatial distribution of the ground surface (Figure 8) in Tianjin Animation Park also shows quite different characteristics: areas close to water have a rather high percentage of green space, while quite a low percentage of building roofs. This might lead to a high quality of waterfront landscape. 
However, areas far away from water have relatively low percentage of green space, where it might rely more on the underground drainage system for pluvial flood alleviation.

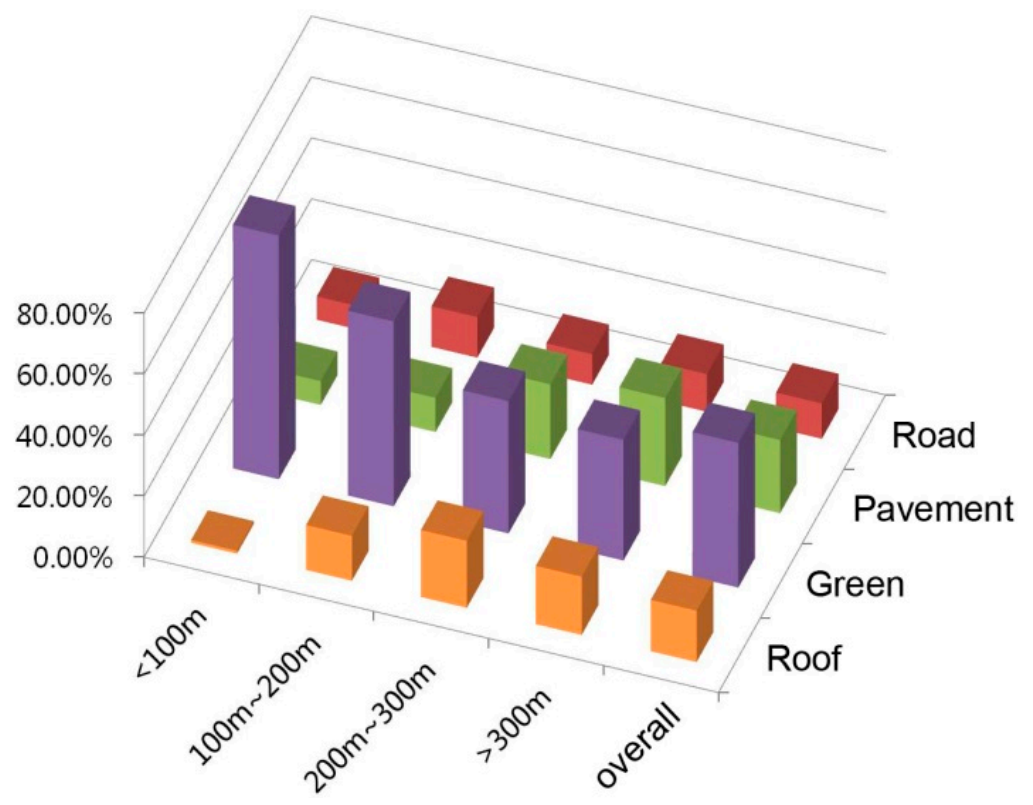

Figure 8. Statistics on ground surface in Tianjin Animation Park.

\subsection{Similarities and Differences}

Located in coastal areas, the two cases both have vast open water surface, serving for storm water retention, but with different spatial structures. The surface water network in Almere is far more densely distributed than in Tianjin Eco-City. Besides waterways are better connected in Almere than the latter.

Comparing the two focus areas, Almere Stad and Tianjin Animation Park are both densely built areas. The former case embodies the thoughts of interweaving urban space with water network, while the latter represents urban development strategies of image branding with vast water surface. Interestingly enough, distribution of four main types of ground surface (building roof, road, pavement, and green space), concerning distance to waterfront, shows great difference in the two focus areas. In Tianjin Animation Park, the farther from waterfront, the more building and pavement are allocated with less green space; while in Almere Stad, it is the opposite.

\section{Determination of Runoff Coefficients in the Two Cases}

As discussed earlier, assuming that the volume of open water and discharging capability is sufficient, and all runoff can be taken by open water system unlimitedly, thus runoff generated on the land plot closer distance to open water can be discharged in a shorter time, thus reducing more risk of flooding during a certain storm event. As the complexity of hydrological simulation is confusing, and even not accessible to many urban planners, a time-into-space concept is brought forward, so that the distance between a certain land plot to open surface water becomes the dependent factor for calculating the "equivalent" weighted average runoff coefficient. This is applied in the two cases discussed in the next paragraphs. 


\subsection{The "Equivalent” Weighted Average Runoff Coefficients in Almere Stad}

Most of the areas in Almere Stad have a weighted average runoff coefficient of around 0.45-0.6, a result that does not consider the influence of surface water system. A weighted average runoff coefficient is calculated by field calculator in ArcGIS based on ground surface typologies, and the results clearly indicate distribution of sealed surfaces (Figure 9). For instance, the block to the north of Weerwater Lake is a commercial area, with a relatively high density of buildings and sealed surface. Its weighted average runoff coefficient reaches 0.69, the highest within Almere Stad. In contrast, the block to the south of Weerwater Lake is a Yacht Port. It has a low density of buildings and less proportion of sealed surface. Its weighted average runoff coefficient is 0.27 , the lowest in Almere Stad.

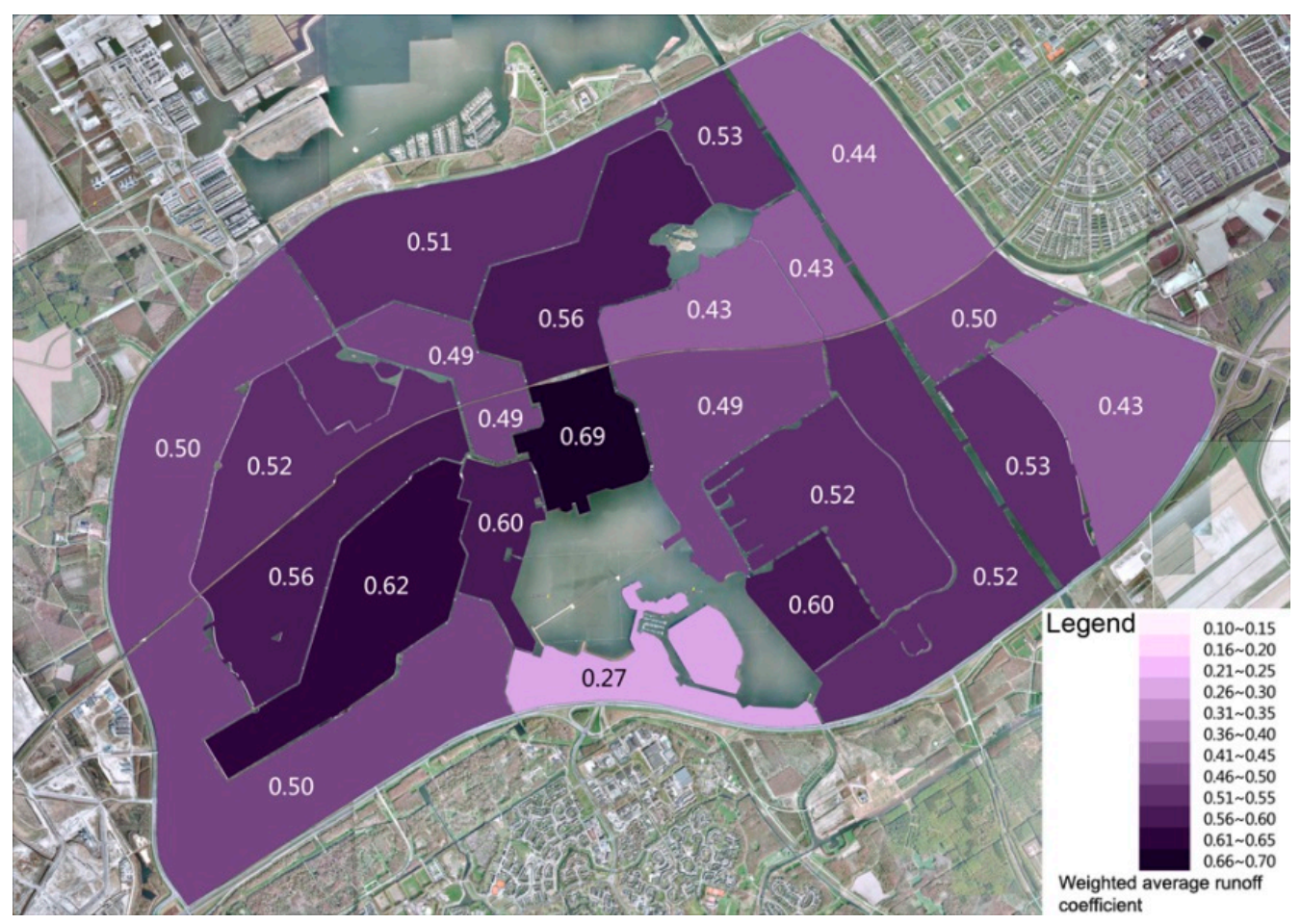

Figure 9. Weighted average runoff coefficient of each block in Almere Stad.

Considering the influence of the surface water systems on pluvial flood alleviation, another ArcGIS analysis shows the "actual" circumstance (Figure 10). In this case, the "equivalent" weighted average runoff coefficients of all the urban blocks are within the range of 0.2-0.45. The number of the central commercial area to the north of the Weerwater Lake is 0.38. Comparing Figure 9 and Figure 10, without considering the influence of the surface water system, the weighted average runoff coefficient of each block varies greatly, since the land use pattern and building density of each block in Almere Stad differs very much. While considering the influence of the surface water system, the "equivalent" weighted average runoff coefficients of the urban blocks become more even. 


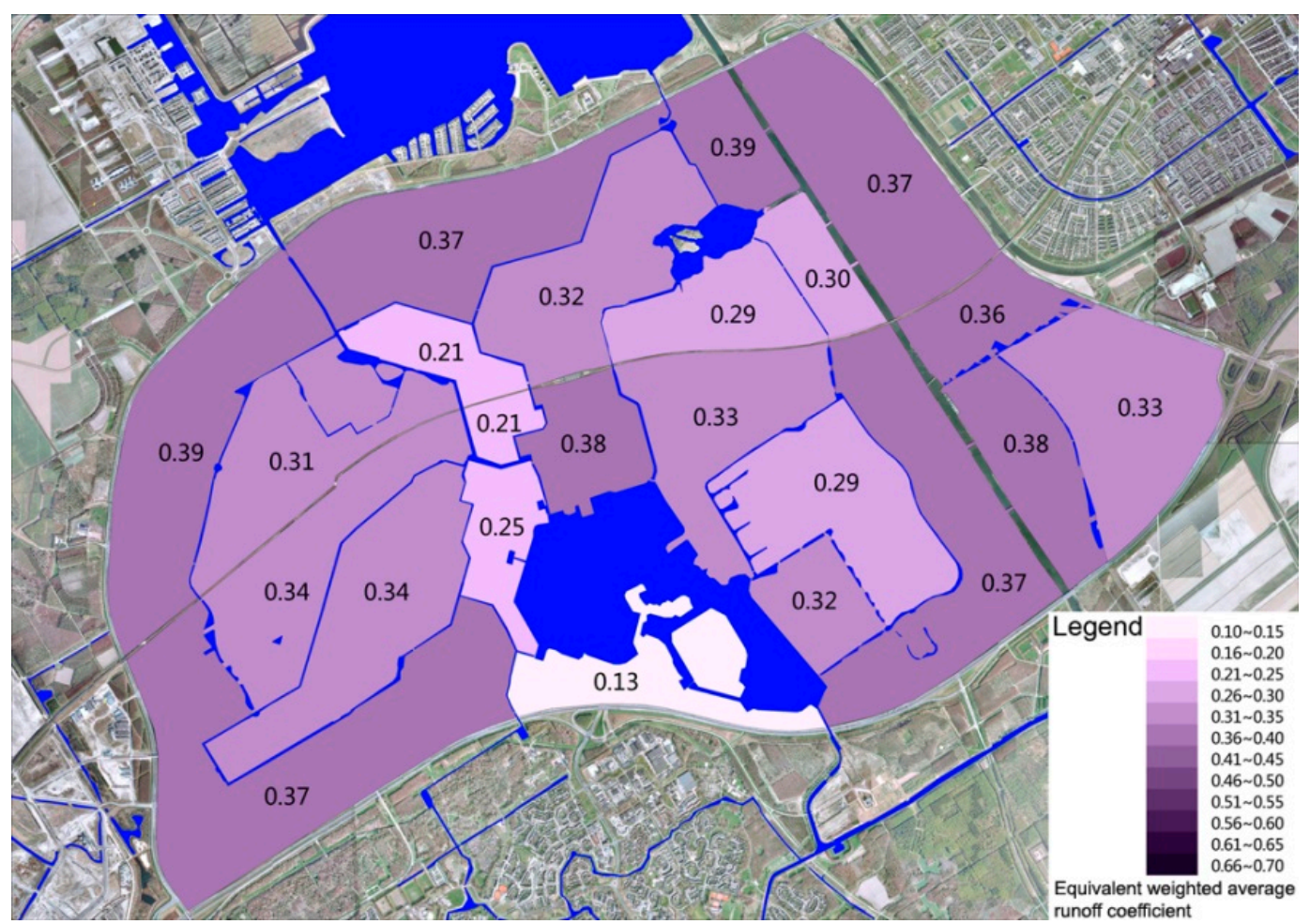

Figure 10. The "equivalent" weighted average runoff coefficient of each block in Almere Stad.

\subsection{The "Equivalent" Weighted Average Runoff Coefficients in Tianjin Eco-City}

The same quantitative analysis made for Almere Stad is also applied in the case of Tianjin Eco-City. Because the most areas in the Tianjin Eco-City is still under construction, this analysis is based on the statutory planning drawings. The four types of ground surface (roof, green space, pavement and road) were classified according to the four waterfront zones (0-100 m, 100-200 m, 200-300 m, and above $300 \mathrm{~m}$ away from the water body). Such classification only included the influence of the old course of Ji Canal. Artificial ponds inside the blocks that are not connected with the surface water system, are not considered when calculating the "equivalent" weighted runoff coefficient. The influence of Ji Canal to the west of the site is also not considered, due to the fact that the flood protection dike has blocked the interaction between the canal and the site.

The calculated result of the weighted average runoff coefficient ranges from 0.38 to 0.62 , while when considering the influence of the surface water system, the number ranges from 0.21 to 0.53 . Figures 11 and 12 show that the level of difference is less in the outer part of the site than in the central area, which is closely surrounded by the old course of Ji Canal. Besides, the general influence from the surface water system in Tianjin Eco-City is much less than in the case of Almere Stad. For example, the "equivalent" weighted average runoff coefficient of Tianjin Animation Park is 0.46. It is slightly lower than the scenario that surface water system is not considered, which is 0.51 . Such a difference is much less than the situation in most of the blocks of Almere Stad. 


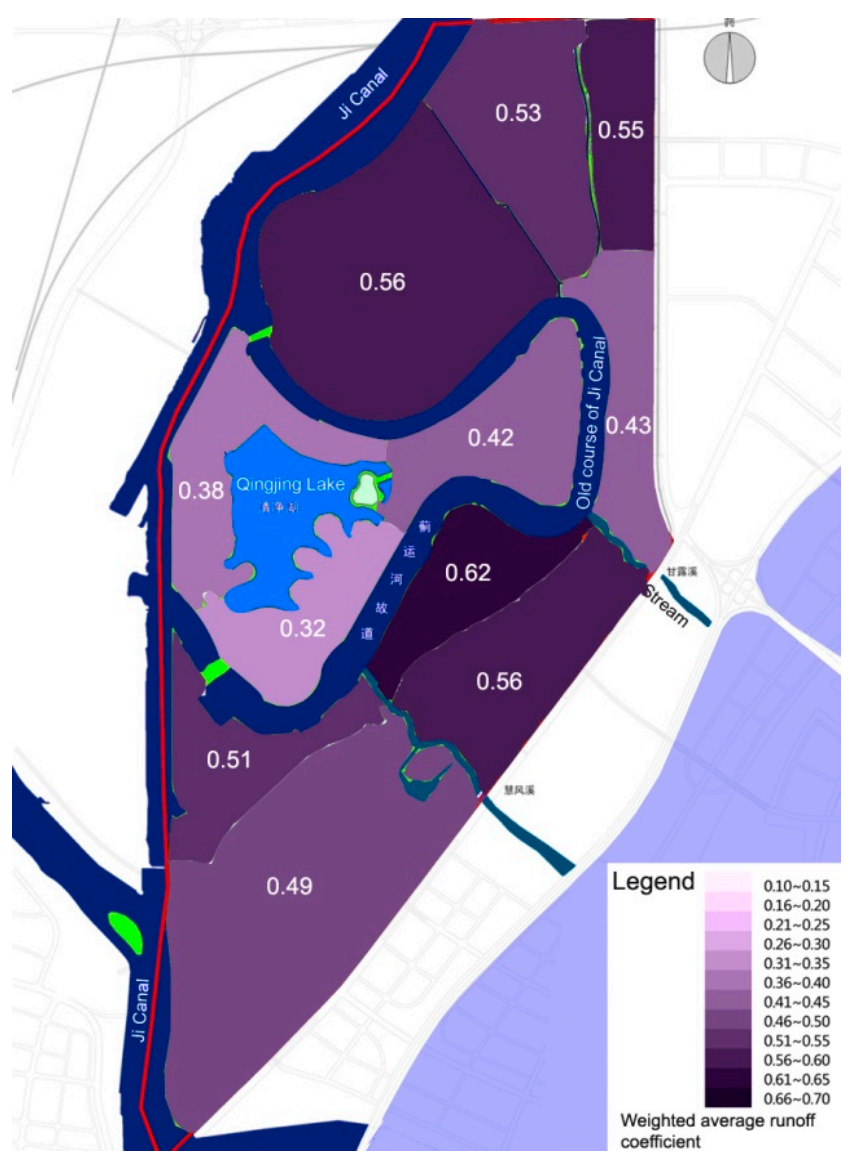

Figure 11. Weighted average runoff coefficient of each block in Tianjin Eco-City.

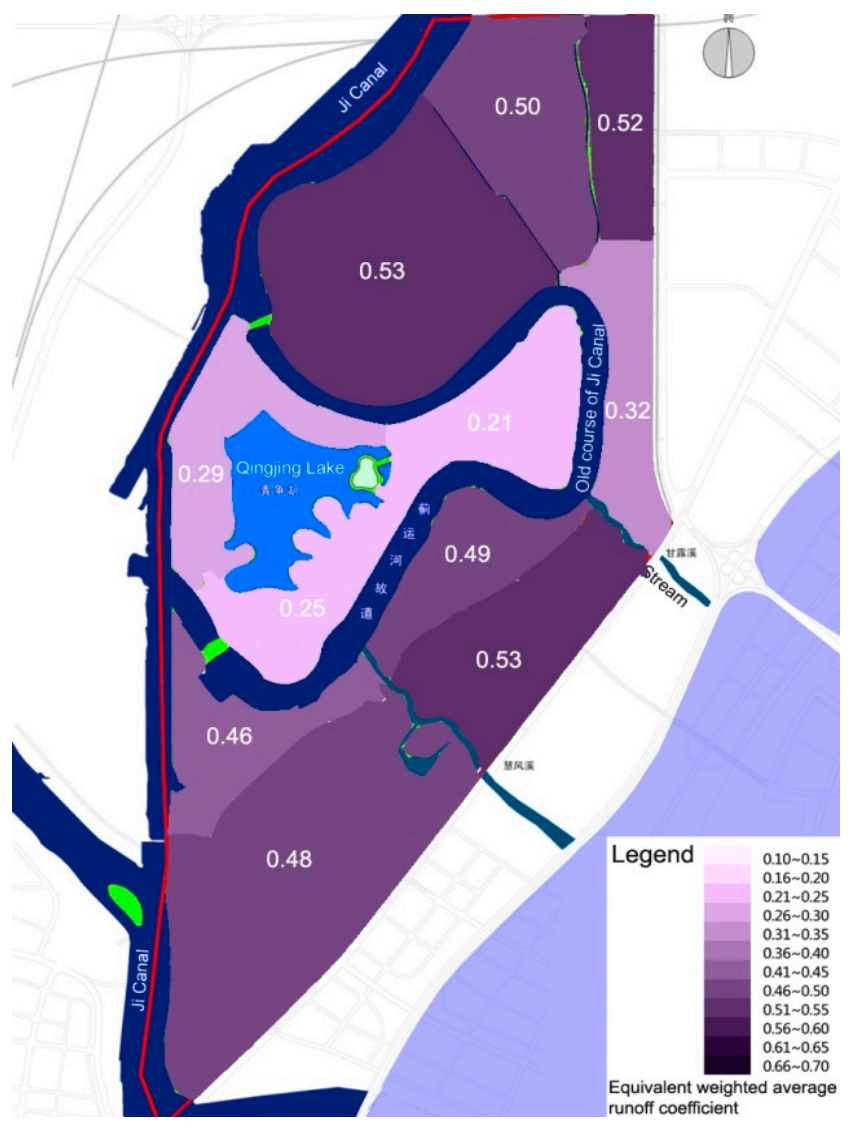

Figure 12. The "equivalent" weighted average runoff coefficient of each block in Tianjin Eco-City. 


\subsection{Similarities and Differences}

As for both cases, the "equivalent" weighted average runoff coefficient decreases to certain extent when considering the influence of the surface water system. However, the level of difference in Almere Stad is much higher than in Tianjin Eco-City. In the cases of Almere Stad, as water ways are more densely distributed, most of the urban blocks could benefit from their proximity to a water body, in terms of reducing the problem of water logging; while in Tianjin Eco-City, since waterways are much wider but less densely distributed, only small parts of the plots share this similar advantage.

\section{Recommendations}

\subsection{A Densely Distributed Open Surface Water Network}

As shown in the comparison of the two case studies, spatial structure of the surface water system is essential in pluvial flood alleviation, with the precondition that there is enough space within the surface water system for collecting and containing storm water locally. Furthermore, a relatively de-concentrated morphology of surface water system works better than a concentrated large water surface.

However, generally speaking, urban development driven by market economy is always pursuing for higher land value and lower cost for public realm, leading to less investment in open space, including surface water system. On the other hand, brandification of urban space usually leads to the fact that surface water is planned and designed mainly for creating city image, without much consideration of flood alleviation. These are contradictory to the notion of sustainable development, especially in the context of global climate change. Cities need to become more adaptive to such changes, for instance the intensive precipitation brought by extreme weather events. A densely distributed open surface water network, with its capacity of containing storm water locally, could be seen as an effective way to achieve this goal.

\subsection{Intervention in Areas farther away from Water Body}

As indicated earlier, the proximity to water body might lead to less problems of water logging. For areas that are farther away from water body, intervention is then needed to reduce the flooding risks. As shown in Figure 13, a quantitative analysis on the case of Almere stad, the number of "equivalent" runoff coefficient of each waterfront zone (defined by every $100 \mathrm{~m}$ ) differs. Areas with darker colors have higher runoff coefficient, which are mostly farther away from the water body. These areas might not be the most vulnerable, suffering from pluvial flooding, but they are the ones that generate the most surface runoff. Having higher standard of underground drainage system, or implementing strategies like LID or BMPs, might be the options there. 


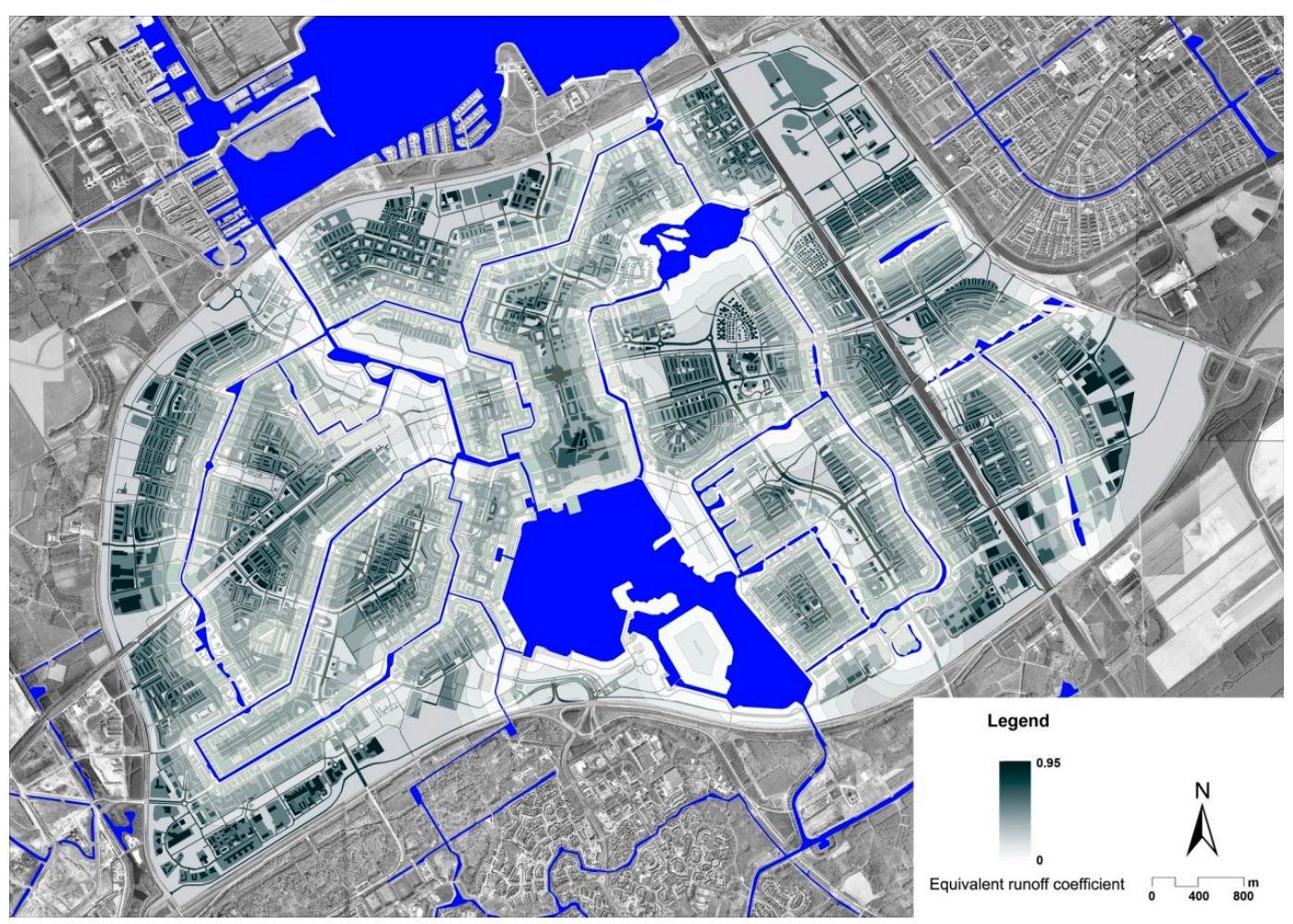

Figure 13. "Equivalent" runoff coefficients of waterfront zones in Almere Stad.

\subsection{Optimizing Ground Surface Planning}

As stated earlier, the four main types of ground surface in urban areas have different runoff coefficients, thus different levels of impact on the risks of water logging: $\Psi_{\mathrm{B}}$ (roof) $=0.95$; $\Psi_{\mathrm{R}}$ (road surface $)=0.85 ; \Psi_{\mathrm{P}}($ pavement $)=0.55$; and $\Psi_{\mathrm{G}}($ green space $)=0.2$. Optimizing the allocation of these four types of ground surfaces in waterfront areas can contribute to pluvial flood alleviation.

For example, building roof has the highest runoff coefficient, meaning that it generates the most surface runoff. According to the calculation shown earlier, it is logical to allocate more buildings close to the surface water system, where surface runoff could be collected and contained. Green space, having the lowest runoff coefficient, generates the least surface runoff. On the one hand, it is logical to allocate more green space in areas far away from the water body in order to avoid water ponding. On the other hand, green area can filter and purify the rainwater runoffs, as well as contribute to the waterfront landscape. Therefore it would be useful to allocate green space near water as well. Furthermore, having green space along the water body could help to create more space for water retention, which is crucial in managing pluvial floods.

\section{Alternative Design for Tianjin Animation Park}

For demonstrating these recommendations, an alternative design for the case of Tianjin Animation Park is made. To optimize the land use planning and urban design of Tianjin Animation Park in line with pluvial flood alleviation, a slightly modified surface water system based on the current layout is proposed. This optimization is mainly achieved by connecting the landscape pond in the middle of the block to the old course of Ji Canal, so as to increase the density of the waterway network within the surface water system. 
In this way, during a rainstorm, rainwater collected in the middle of the block could be quickly directed into the old course of Ji Canal, which will function as water retention (Figure 14). The calculation result of the "equivalent" weighted average runoff coefficient based on this modified proposal for Tianjin Animation Park is 0.36, showing a noticeable difference.

Statistics generated from this proposal show that the spatial distribution of ground surface typologies is quite comparable to the case of Almere Stad (Figure 15).

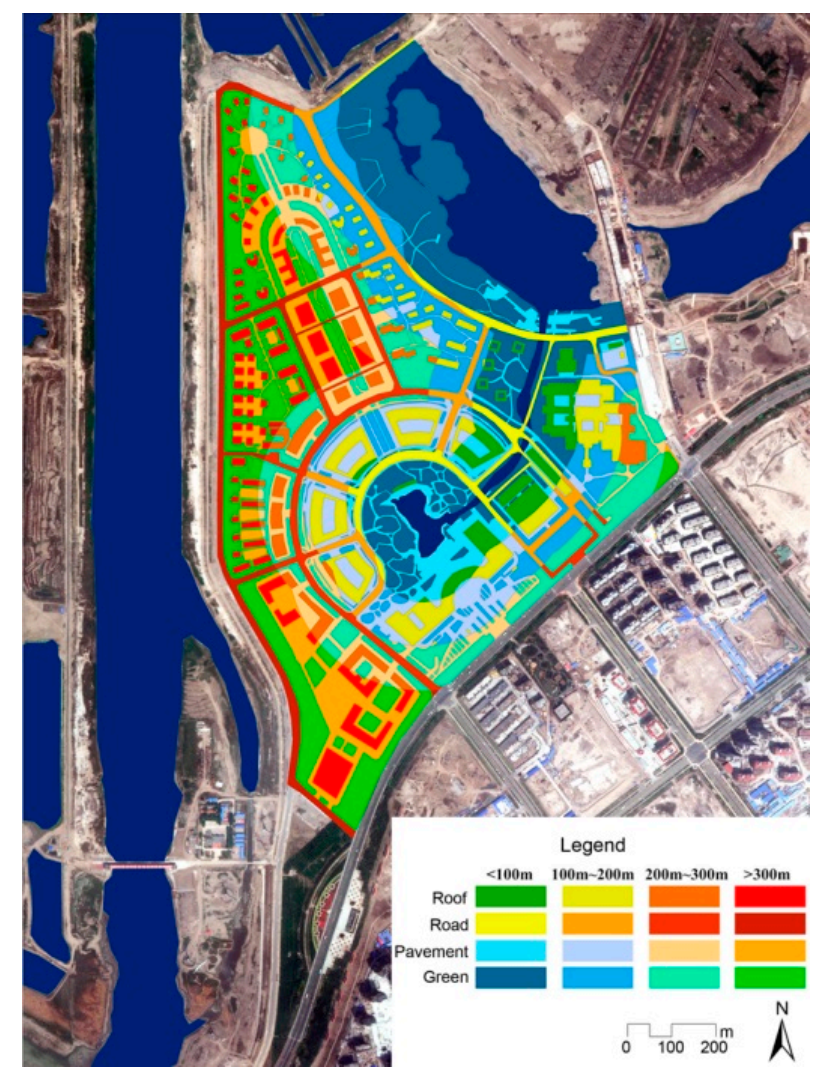

Figure 14. Spatial distribution of ground surface typologies (the modified proposal of Tianjin Animation Park).

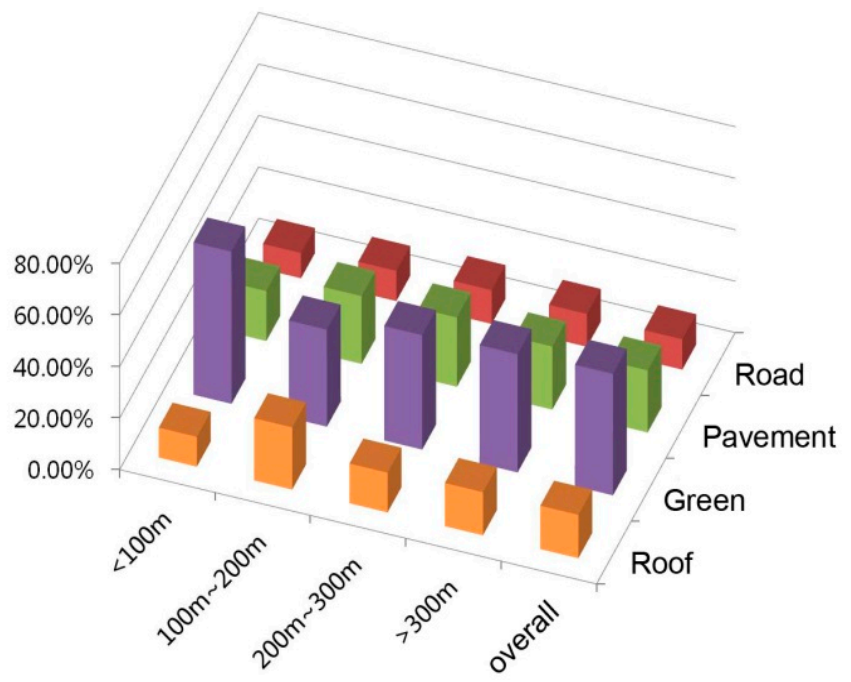

Figure 15. Statistics on the spatial distribution of ground surface typologies (the modified proposal of Tianjin Animation Park). 


\section{Conclusions and Outlook}

Generally speaking, the conventional flood management systems are rather vulnerable when coping with extreme weather events. On the one hand, the current standard for underground sewer system forms a "bottle neck" for storm water drainage, which is accordingly not climate adaptive. On the other hand, the capacity of water retention systems within built up areas is also limited, due to the issue of space availability. Thus, creating largely distributed open surface water system is essential for pluvial flood alleviation, forming a climate adaptive scheme for urban development.

The quantitative analysis shown in this paper is made to guide planning and design of the urban surface water system in new towns, concerning pluvial flood alleviation. It also involves optimizing the allocation of ground surface typologies in waterfront areas. The guidelines and principles have been introduced in Section 5 as recommendations.

Other correlated concepts and design methods, such as LID, BMPs and Water Sensitive Urban Design, which have been largely used in practice worldwide, can be considered as means of pluvial flood management, and, furthermore, contribution to a higher spatial quality of the living environment. These aspects could be integrated more with the quantitative approaches in further research and practice, as what this paper has been attempting to demonstrate. Such multi-disciplinary approach might generate more comprehensive guidelines for urban planners and designers, when dealing with pluvial flood risks in new town development. With the support of these guidelines, spatial planning and design might also contribute effectively to the reduction of pluvial flood risks.

\section{Acknowledgments}

This paper is supported by the International Science \& Technology Cooperation Program of China (2010DFA74490) and special fund of Key Laboratory of Eco Planning \& Green Building, Ministry of Education (Tsinghua University), China.

\section{Author Contributions}

Zhengnan Zhou designed research; Lei Qu completed Introduction section and literature research; Zhengnan Zhou and Tao Zou performed research and analyzed the data; all authors participated in writing the paper. All authors read and approved the final manuscript.

\section{Conflicts of Interest}

The authors declare no conflict of interest.

\section{References}

1. Karl, T.R.; Trenberth, K.E. Modern Global Climate Change. Science 2003, 302, 1719-1723. 
2. Seneviratne, S.I.; Nicholls, N.; Easterling, D.; Goodess, C.M.; Kanae, S.; Kossin, J.; Luo, Y.; Marengo, J.; McInnes, K.; Rahimi, M.; et al. Changes in climate extremes and their impacts on the natural physical environment. In Managing the Risks of Extreme Events and Disasters to Advance Climate Change Adaptation; Field, C.B., Barros, V., Stocker, T.F., Qin, D., Dokken, D.J., Ebi, K.L., Mastrandrea, M.D., Mach, K.J., Plattner, G.K., Allen, S.K., et al., Eds.; Cambridge University Press: Cambridge, UK; New York, NY, USA, 2012; pp. 109-230.

3. Guhathakurta, P.; Sreejith, O.P.; Menon, P.A. Impact of Climate Change on Extreme Rainfall Events and Flood Risk in India. J. Earth Syst. Sci. 2011, 120, 359-373.

4. Hejazi, M.; Markus, M. Impacts of Urbanization and Climate Variability on Floods in Northeastern Illinois. J. Hydrol. Eng. 2009, 14, 606-616.

5. Dearden, R.A.; Price, S.J. A Proposed Decision Making Framework for a National Infiltration SuDS Map. Manag. Environ. Qual. Int. J. 2012, 23, 478-485.

6. The Ministry of Housing and Urban-Rural Development of the People's Republic of China. Code for Design of Outdoor Wastewater Engineering (GB 50014-2006); China Planning Press: Beijing, China, 2006.

7. The Ministry of Housing and Urban-Rural Development of the People's Republic of China. Code for Design of Outdoor Wastewater Engineering (GB 50014-2006); China Planning Press: Beijing, China, 2011.

8. European Committee for Standardization. European Standard for Planning, Design and Operation of Drain and Sewer Systems Outside Buildings (EN 752); British Standards Institution (BSI): London, UK, 2008.

9. National Menu of Stormwater Best Management Practices. Available online: http://water.epa.gov/ polwaste/npdes/swbmp/ (accessed on 11 September 2015).

10. Ashley, R.M.; Tait, S.J.; Styan, E.; Cashman, A.; Luck, B.; Blanksby, J.; Saul, A.; Sandlands, L. Sewer System Design Moving into the 21st Century-A UK Perspective. Water Sci. Technol. 2007, 55, 273-281.

11. Price, R.K.; Vojinovic, Z. Urban Flood Disaster Management. Urban Water J. 2008, 5, 259-276.

12. Tait, S.J.; Ashley, R.M.; Cashman, A.; Blanksby, J.; Saul, A.J. Sewer System Operation into the 21st Century: Study of Selected Responses from a UK Prospective. Urban Water J. 2008, 5, 79-88.

13. Fratini, C.F.; Geldofac, G.D.; Kluckd, J.; Mikkelsena, P.S. Three Points Approach (3PA) for Urban Flood Risk Management: A Tool to Support Climate Change Adaptation through Transdisciplinarity and Multifunctionality. Urban Water J. 2012, 9, 317-331.

14. National Water Plan 2009-2015. Available online: http://publicaties.minienm.nl/documenten/ national-water-plan-2009-2015 (accessed on 23 September 2015).

15. Koomen, E.; Borsboom-van Beurden, J. Land-Use Modeling in Planning Practice; Springer: Heidelberg, Germany, 2011.

16. De Graaf, R.; van der Brugge, R. Transforming Water Infrastructure by Linking Water Management and Urban Renewal in Rotterdam. Technol. Forecast. Soc. Chang. 2010, 77, 1282-1291.

17. Schuetze, T.; Chelleri, L. Integrating Decentralized Rainwater Management in Urban Planning and Design: Flood Resilient and Sustainable Water Management Using the Example of Coastal Cities in The Netherlands and Taiwan. Water 2013, 5, 593-616. 
18. Spekkers, M.H.; ten Veldhuis, J.A.E.; Clemens, F.H.L.R. Collecting Data for Quantitative Research on Pluvial Flooding. In Proceedings of the 12th International Conference on Urban Drainage, Porto Alegre, Brazil, 11-16 September 2011; pp. 461-466.

19. Granato, G.E. Statistics for Stochastic Modeling of Volume Reduction, Hydrograph Extension, and Water-quality Treatment by Structural Stormwater Runoff Best Management Practices (BMPs). Available online: http://pubs.usgs.gov/sir/2014/5037/ (accessed on 11 September 2015).

20. Martin, C.; Ruperd, Y.; Legret, M. Urban Stormwater Drainage Management: the Development of a Multicriteria Decision Aid Approach for Best Management Practices. Eur. J. Oper. Res. 2007, $181,338-349$.

21. Kerby, W.S. Time of Concentration for Overland Flow. Civil Eng. 1959, 29, Article 60.

22. Wong, T.S.W.; Chen, C.N. Time of Concentration Formula for Sheet Flow of Varying Flow Regime. J. Hydrol. Eng. 1997, 2, 136-139.

23. Cleveland, T.G.; Thompson, D.B.; Fang, X.; Li, M.H. Guidance for Estimation of Time of Concentration in Texas for Low-Slope Conditions. Available online: http://www.depts.ttu.edu/ techmrtweb/Reports/Products/0-6382-P1.pdf (accessed on 10 September 2015).

24. Zhou, Y.; Meng, Z.; Wang, M. Precipitation Runoff Simulation Modeling by Isochronal Method for Urban Inlet Basin Watershed. J. Shenyang Archit. Civil Eng. Inst. 1994, 10, 339-344. (In Chinese)

25. Wong, T.S.W. Assessment of Time of Concentration Formulas for Overland Flow. J. Irrig. Drain. Eng. 2005, 131, 383-387.

26. Kadioglu, M.; Sen, S. Monthly Precipitation-runoff Polygons and Mean Runoff Coefficients. Hydrol. Sci. J. 2001, 46, 3-11.

27. Jak, M.; Kok, M. A Database of Historical Flood Events in the Netherlands. In Flood Issues in Contemporary Water Management; Marsalek, J., Watt, W.E., Zeman, E., Sieker, F., Eds.; Kluwer Academic Publishers: Dordrecht, The Netherlands, 2000; pp. 139-146

28. Hoes, O.; Schuurmans, W. Flood Standards or Risk Analyses for Polder Management in the Netherlands. Irrig. Drain. 2006, 55, 113-119.

29. Brauer, C.C.; Teuling, A.J.; Overeem, A.; van der Velde, Y.; Hazenberg, P.; Warmerdam, P.M.M.; Uijlenhoet, R. Anatomy of Eextraordinary Rainfall and Flash Flood in a Dutch Lowland Catchment. Hydrol. Earth Syst. Sci. 2011, 15, 1991-2005.

(C) 2015 by the authors; licensee MDPI, Basel, Switzerland. This article is an open access article distributed under the terms and conditions of the Creative Commons Attribution license (http://creativecommons.org/licenses/by/4.0/). 